\title{
Pandemic H1N1 2009 in Neonates
}

\author{
Viroj Wiwanitkit
}

Received: 6 September 2010 /Accepted: 30 September 2010/Published online: 8 October 2010

(C) Dr. K C Chaudhuri Foundation 2010

Sir,

I read the recent publication on pandemic H1N1 2009 in neonates with a great interest. Hon et al. concluded that "Emergency room and frontline staff must be vigilant of the non-specific clinical features of infections with respiratory viruses in the neonates so that prompt triage and isolation can be implemented to avoid outbreaks in the neonatal service [1]." Of the studied cases, there was no pandemic H1N1 2009 in this series [1]. I agree that the pandemic H1N1 2009 can be a serious infection among neonate but the null prevalence in this report might imply some clinical importance. It is still a myth whether neonate has some specific mechanism that brings resistance to infection. In the series of infection in pregnant subjects, the transmission to the child is very low [2]. Indeed, the first case report of neonatal pneumonia has just been published in July 2010 [3].

\section{References}

1. Hon KL, Cheung KL, Wong W, Ng PC. Neonates Investigated for Influenza-Like Illness During the Outbreak of Pandemic H1N1 2009: Trivial Infections But Major Triage Implications. Indian J Pediatr. 2010 Sep 3. [Epub ahead of print]

2. Jamieson DJ, Honein MA, Rasmussen SA, et al. Novel Influenza A (H1N1) Pregnancy Working Group. H1N1 2009 influenza virus infection during pregnancy in the USA. Lancet. 2009;374:451-8.

3. Sert A, Yazar A, Odabas D, Bilgin H. An unusual cause of fever in a neonate: influenza A (H1N1) virus pneumonia. Pediatr Pulmonol. 2010;45:734-6.

\footnotetext{
V. Wiwanitkit $(\bowtie)$

Wiwanitkit House, Bangkhae,

Bangkok, Thailand 10160

e-mail: wviroj@yahoo.com
}

\section{Author's reply}

Sir,

Professor Wiwanitkit's comment that it is still a myth whether neonate has some specific mechanism that brings resistance to infection is interesting. In the cited series of infection in pregnant subjects, the 5 neonates, born between 27 and 36 wks gestation, were not infected by the H1N1 [1]. In a previous series of SARS-CoV (Severe Acute Respiratory Syndrome - Coronavirus) infection in pregnant women, infants born to mothers with the respiratory viral infection did not acquire the infection through vertical transmission [2].

The first case report of H1N1 neonatal pneumonia has been published [3]. I wonder if there are any more cases of neonatal H1N1 elsewhere in the world. We have since managed a dozen of neonates with RSV infections in the early months of 2010 but no H1N1 to date. These neonates did not require ICU support and were only managed symptomatically.

1. Shek CC, Ng PC, Fung GPG et al. Infants born to mothers with severe acute respiratory syndrome. Pediatrics 2003;112:e254-e256.

2. Jamieson DJ, Honein MA, Rasmussen SA et al. Novel Influenza A (H1N1) Pregnancy Working Group. H1N1 2009 influenza virus infection during pregnancy in the USA. Lancet 2009;374:451-8.

3. Sert A, Yazar A, Odabas D, Bilgin H. An unusual cause of fever in a neonate: influenza A (H1N1) virus pneumonia. Pediatr Pulmonol 2010;45:734-6.

\section{Dr.Kam-Lun Ellis Hon}

Department of Pediatrics,

The Chinese University of Hong Kong,

6/F, Clinical Sciences Building, Prince of Wales Hospital, Shatin, Hong Kong SAR, China.

E-mail: ehon@hotmail.com 